\title{
ANALISIS KESULITAN PENGUASAAN KONSEP TEORITIS DAN PRAKTIKUM KIMIA MAHASISWA CALON GURU KIMIA
}

\author{
Yenni Kurniawati ${ }^{1)}$ \\ ${ }^{1}$ Program Studi Pendidikan Kimia, Fakultas Tarbiyah dan Keguruan, \\ Universitas Islam Negeri Sultan Syarif Kasim Riau \\ yenni.kurniawati@uin-suska.ac.id
}

\begin{abstract}
The difficulties of preservice chemistry teacher in understanding theoretical and experimental chemistry were needed to be explored. This research was conducted to analyze students' difficulties in understanding theoretical and experimental chemistry courses, to obtained information that can be used as an evaluation for lecturers and faculty in an effort to improve the quality of preservice chemistry teacher. Mixed method with embedded design was used in this research by given priority to qualitative data as core and quantitative data to supported the analysis. This research found that teoretical inorganic and physical chemistry objects were the most difficult course for fifth semester students, whereas for the seventh graders physical and instrumental chemistry was the most difficult. The main causes of difficulty for students was the chemical abstractions plus the mathematic analysis that was not easily to deep understood by the students. Studets learning patterns and learning design are things that need to be improve to get better results.
\end{abstract}

Kata Kunci: Kesulitan Mahasiswa, Kimia Teoritis, Praktikum Kimia

\section{PENDAHULUAN}

Kimia merupakan salah satu cabang ilmu sains yang perkembangan pengetahuan dasar dan aplikasinya membutuhkan kerja eksperimental dengan standar tertentu. Hasilhasil eksperimen kimia yang dilakukan sesuai standar akan menghasilkan kebaharuan baik dalam bidang ilmu pengetahuan pendukung temuan selanjutnya, maupun menjadi produkproduk yang bermanfaat di berbagai bidang.

Guna mengembangkan ilmu kimia dan aplikasinya, dibutuhkan selalu generasi muda yang secara berkesinambungan mempelajari ilmu kimia. Pembekalan ilmu ini secara spesifik diberikan di jenjang perguruan tinggi, melalui pembekalan ilmu kimia teoritis dan eksperimen yang disajikan secara sistematis dan saling berhubungan dalam kurikulum pada program pendidikan calon guru kimia.

Bagi mahasiswa calon guru kimia, keterampilan beksperimen kimia yang baik membutuhkan pemahaman konsep kimia mulai dari sebelum, selama, dan setelah kegiatan eksperimen[1], sebaliknya eksperimen kimia tidak akan dapat terlaksana dengan optimal tanpa pemahaman konsep yang baik[2]. Keduanya saling berhubungan dan saling dukung bagi pembelajaran kimia, karena secara empiris telah terbukti bahwa untuk memahami ilmu kimia dengan baik sangat tergantung oleh pengalaman terutama pengajaran yang berbasiskan eksperimen[3].

Dalam pelaksanaan pembelajaran kimia bagi calon guru kimia di perguruan tinggi, materi kimia teoritis pada umumnya disajikan bersandingan dengan kegiatan eksperimen kimia. Eksperimen kimia dilakukan dalam kegiatan terstruktur dalam bentuk praktikum kimia. Praktikum kimia di laboratorium merupakan suatu aktifitas yang membantu mahasiswa tidak hanya untuk meningkatkan pemahaman konseptual dan kognitif mereka, tapi juga membentuk keterampilan teknis seperti manipulasi, penelitian, pengumpulan data, proses dan analisis data, interpretasi penelitian, pemecahan masalah, kerja tim, desain percobaan, keterampilan berkomunikasi dan lainnya [4]. Namun demikian, dalam 
pelaksanaannya banyak kelemahan, kendala dan kesenjangan yang terjadi. Diantaranya, tidak terlihatnya hubungan yang signifikan antara kemampuan pemahaman konsep dengan keterampilan bereksperimen dan sebaliknya [5].

Diperkirakan banyak faktor yang menyebabkan beragam permasalahan yang menghambat tercapainya keterampilan bereksperimen dan kemampuan penguasaan konsep yang dimiliki mahasiswa secara sinergis. Oleh karenanya diperlukan suatu cara yang efektif untuk membantu mahasiswa meningkatkan pemahaman mereka akan ilmu kimia secara utuh, memahami hubungan konsep dengan eksperimen serta manfaat praktikum dalam keseharian.

Untuk mengetahui solusi yang dibutuhkan, terlebih dahulu perlu dianalisis kelemahan dan kesulitan ini guna menemukan jalan keluar terbaik. Dibutuhkan penelitian yang terkait dengan kesulitan mahasiswa dan pandangan mereka terhadap praktikum kimia yang telah mereka laksanakan selama ini, dan hubungannya dengan konsep kimia teoritis yang mereka peroleh.

Tujuan dari penelitian ini adalah untuk menggali dan menganalisis jejak kesulitan mahasiswa terhadap praktikum kimia yang mereka jalani selama ini dan hubungannya dengan pengetahuan konsep yang mereka pahami, pola pandang dan cara belajar mereka dalam mempersiapkan penguasaan materi sebelum praktikum, serta usaha mereka mengatasi kesulitan selama praktikum.

\section{METODE PENELITIAN}

Penelitian ini dilakukan dengan menggunakan pendekatan mixed method with embedded design, di mana data penelitian utama bersifat kualitatif, dengan melakukan 'embedded' data kuantitatif ke dalam analisisnya [6] untuk menjelaskan kondisi yang ditemukan. Kuantifikasi terhadap data kualitatif dilakukan secara teintegrasi guna memberikan penjelasan yang lebih detail pada data kualitatif yang diperoleh.

Subyek penelitian ini adalah 100 orang mahasiswa calon guru kimia semester $\mathrm{V}$ Jurusan Pendidikan Kimia Universitas Islam Negeri Sulthan Syarif Kasim Riau, yang dipilih secara acak. Dosen dan laporan juga dilibatkan dalam penelitian ini guna akurasi data.

Objek penelitian ini adalah kesulitan mahasiswa dalam melaksanakan kegiatan eksperimen kimia, dan hubungannya dengan penguasaan konsep mereka. Pola pikir dan cara pandang mereka terhadap kedua kegiatan pembelajaran ini juga akan menjadi objek yang diteliti, guna memperdalam analisis kesulitan mahasiswa.

Teknik pengumpulan data dilakukan dengan mengidentifikasi beberapa kegiatan praktikum kimia yang telah dan sedang dilakukan mahasiswa, bersamaan dengan materi kimia teoritis yang telah atau sedang dilalui. Selain itu, diberikan angket tertutup dan terbuka kepada mahasiswa semester V dan VII secara terpisah dengan format yang sama.

Angket terbuka diberikan pada mahasiswa guna memberikan peluang bagi mahasiswa menjelaskan ragam kesulitan mereka dalam memahami konsep kimia, dan kendala yang mereka alami dalam praktikum kimia. Jawaban yang paling dominan akan menjadi data penting terkait kesulitan mahasiswa. Angket tertutup diberikan guna melihat pola pandang dan persepsi mereka terhadap kesulitan perkuliahan teori dan praktikum, serta upaya yang mereka lakukan untuk mengatasinya. Wawancara terhadap mahasiswa, asisten dan dosen pembimbing praktikum juga dilakukan untuk mendukung data hasil penelitian. Selain itu, analisis dokumen juga dilakukan terhadap hasil evaluasi beberapa praktikum kimia terkait. Data-data kualitatif dalam penelitian ini dikuantifikasikan dalam bentuk skala (data interval).

\section{HASIL DAN PEMBAHASAN}

Penelitian ini menghasilkan beberapa temuan terkait beberapa kesulitan mahasiswa dalam menguasai materi kimia teoritis dan praktikum kimia serta persepsi mahasiswa terhadap kendala dan permasalahan yang mereka alami. Temuan awal yang diperoleh adalah persepsi mahasiswa terhadap pilihan mata kuliah yang mereka anggap sulit untuk dikuasai, baik mata kuliah teoritis dan praktikumnya, sebagaimana terlihat pada Gambar 1 (a) dan (b). 


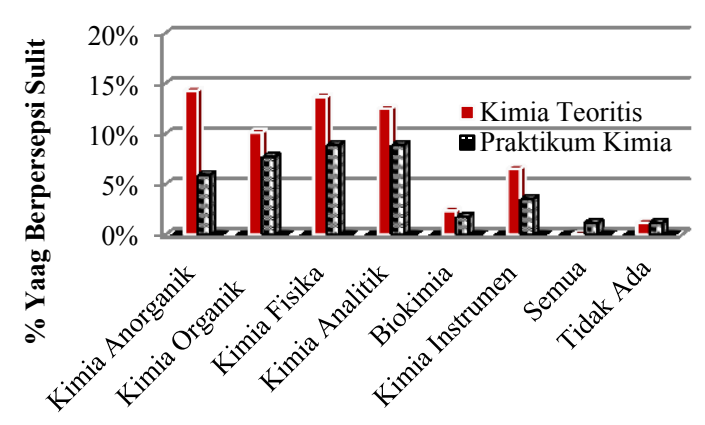

(a)

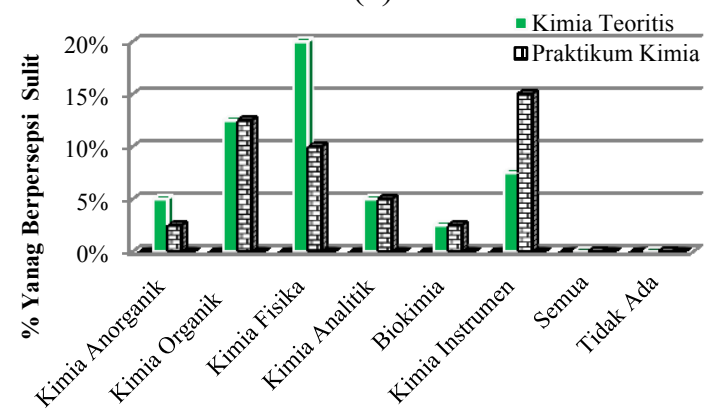

(b)

Gambar 1. Perbandingan persentasi mahasiswa semester V(a) dan VII(b) yang berpersepsi sulit terhadap mata kuliah kimia teoritis dengan praktikum kimia

Dari grafik yang terlihat di atas diperoleh informasi terlihat bahwa Praktikum Kimia Analitik dan Kimia Fisika merupakan mata praktikum tersulit menurut persepsi mahasiswa semester V, sedangkan bagi mahasiswa semester VII, Praktikum Kimia Instrumen adalah mata praktikum tersulit bagi mereka. Untuk mata kuliah kimia teoritis, dari Gambar 1 juga terlihat bahwa mahasiswa semester $\mathrm{V}$ menganggap Kimia Anorganik sebagai mata kuliah tersulit, yang disusul dengan mata kuliah Kimia Fisika dan Kimia Analitik. Namun pada mahasiswa semester VII, kesulitan mereka hanya terlihat pada mata kuliah Kimia Fisika. Dalam hal in mahasiswa semester V dan VII memiliki perbedaan pendapat tentang mata kuliah praktikum kimia mana yang mereka anggap sulit, dan mengapa mereka menganggapnya sulit.

Untuk Praktikum Kimia Analitik dan Kimia Fisika, kesulitan mahasiswa perlu dikaitkan dengan karakteristik praktikum ini, yang mana keduanya merupakan mata kuliah praktikum yang banyak membutuhkan hitungan, maka terlihat jelas bahwa kemampuan hitungan matematika kimia mahasiswa kurang memadai. Pemahaman tentang teori kimia yang bersifat abstrak juga terlihat disini, dimana kimia organik dan praktikumnya juga menjadi salah satu mata kuliah dan praktikum yang dianggap sulit bagi mahasiswa. Untuk praktikum kimia Instrumen yang menurut mahasiswa semester VII adalah yang tersulit, ternyata disebabkan karena banyaknya instrumentasi kimia yang kurang berfungsi dengan baik, sehingga mahasiswa kesulitan memahaminya dengan baik.

Secara detail, kesulitan mahasiswa dalam melaksanakan dan memahami kegiatan praktikum dengan baik, digali dalam penelitian ini. Hasilnya ternyata masing masing mahasiswa memiliki kesulitan yang beragam, sebagaimana yang dirangkum terlihat pada Tabel 1.

Tabel 1. Kesulitan Praktikum Kimia bagi mahasiswa

\begin{tabular}{lcc}
\hline \multicolumn{1}{c}{$\begin{array}{c}\text { Kesulitan-Kesulitan } \\
\text { Mahasiswa }\end{array}$} & Sem V & SemVII \\
\hline $\begin{array}{l}\text { Memahami prosedur } \\
\text { percobaan }\end{array}$ & $13 \%$ & $0 \%$ \\
$\begin{array}{l}\text { Memahami manfaat } \\
\text { praktikum dalam } \\
\text { aplikasinya }\end{array}$ & $16 \%$ & $2 \%$ \\
$\begin{array}{l}\text { Memahami reaksi kimia } \\
\text { yang berlangsung }\end{array}$ & $47 \%$ & $11 \%$ \\
$\begin{array}{l}\text { Menggunakan alat } \\
\text { dengan baik dan aman }\end{array}$ & $18 \%$ & $2 \%$ \\
$\begin{array}{l}\text { Data yang diperoleh sulit } \\
\text { untuk diinterpretasikan }\end{array}$ & $31 \%$ & $13 \%$ \\
$\begin{array}{l}\text { Menjawab pertanyaan } \\
\text { yang merupakan analisis } \\
\text { hasil praktikum }\end{array}$ & $27 \%$ & $0 \%$ \\
$\begin{array}{l}\text { Hitungannya sulit untuk } \\
\text { dianalisis }\end{array}$ & $22 \%$ & $7 \%$ \\
$\begin{array}{l}\text { Memahami proses pada } \\
\text { skala mikro yang } \\
\text { bersifat abstrak }\end{array}$ & $42 \%$ & $13 \%$ \\
$\begin{array}{l}\text { Menjawab pertanyaan } \\
\text { yang merupakan analisis } \\
\text { hasil praktikum }\end{array}$ & $27 \%$ & $0 \%$ \\
$\begin{array}{l}\text { Memahami keterkaitan } \\
\text { percobaan dalam } \\
\text { praktikum dengan teori } \\
\text { di kelas }\end{array}$ & $29 \%$ & $29 \%$ \\
\hline Tidak ada & $0 \%$ & $0 \%$ \\
\hline
\end{tabular}


Dari data Tabel 1 terlihat bahwa kemampuan menyelesaikan reaksi yang berlangsung selama proses eksperimen dan memahami proses mikroskopik yang terjadi, menunjukkan bahwa kesulitan mahasiswa yang paling dominan adalah karena mereka mengalami kesulitan menvisualisasikan abstraksi kimia molekular dengan baik. Selain itu, kesulitan mahasiswa yang dominan adalah kemampuan mereka dalam 'menganalisis', yang merupakan salah satu kemampuan berpikir tingkat tinggi. Padahal, kompetensi profesional guru kimia sesuai penjabaran yang tertuang dalam lampiran Permendikbud Nomor 16 Tahun 2007 poin 20 adalah 1) harus menguasai konsep kimia 2) memahami proses berpikir kimia, 3) terampil bereksperimen, 4) melakukan refleksi terhadap kinerja. Artinya, seorang calon guru kimia harus memiliki kemampuan berpikir tingkat tinggi yang baik, selain terampil dalam bereksperimen. Hal ini menunjukkan bahwa masih dibutuhkannya upaya yang dilakukan oleh pendidik dan institusi di perguruan tinggi, guna mendukung peningkatan kemampuan mahasiswa calon guru kimia.

Hasil penelitian ini menunjukkan bahwa kesulitan mahasiswa dalam melaksanakan kegiatan praktikum dan pemahamannya memiliki sebab-sebab yang beragam, selain terdapat perbedaan tingkat pemahaman dari mereka dan perbedaan kualitas dan kuantitas pengalaman mereka selama mengikuti praktikum kimia. Untuk keterampilan 'hands on' bagi mahasiswa, permasalahan seperti kompleksnya kemampuan yang dibutuhkan untuk melaksanakan percobaan, sulitnya menggabungkan lebih dari satu keterampilan proses ilmiah dan dibutuhkannya kemampuan berpikir tingkat tinggi[7], dan kurangnya kualitas dan kuantitas latihan laboratorium yang mereka peroleh juga dapat menjadi faktor yang berperan dalam hal ini [5][7], ditambah dengan belum optimalnya fasilitas alat dan bahan untuk praktikum, merupakan alasan pembeda persepsi mahasiswa di jenjang yang berbeda.

Bila dianalisis kesulitan mahasiswa dalam memahami materi kimia, terlihat bahwa mayoritas mahasiswa memiliki kesulitan yang identik dengan praktikum kimia, yakni terkait sulitnya memahami reaksi yang bersifat abstrak, dan menganalisis hitungan kimia. Bila dilihat dari beberapa studi sebelmnya, kesulitan ini disebabkan oleh karena karakteristik penting dari ilmu kimia yang mencakup interaksi konstan antara pemikiran level makroskopik dan mikroskopik, serta pemahaman aspek kimia dan fisika yang merupakan tantangan yang signifikan bagi pemula[8], di mana hubungan antara level ini harus diajarkan secara eksplisit [9]. Secara rinci, sebab-sebab kesulitan mereka memahami mata kuliah yang bersifat teoritis ini dapat terlihat dari Tabel 2.

Tabel 2. Sebab-Sebab Kesulitan Mahasiswa Memahami Konsep Kimia

\begin{tabular}{|c|c|c|}
\hline \multirow{2}{*}{$\begin{array}{l}\text { Penyebab } \\
\text { Kesulitan }\end{array}$} & \multicolumn{2}{|c|}{ Jenjang Mahasiswa } \\
\hline & $\begin{array}{c}\text { Semester } \\
\mathrm{V}\end{array}$ & $\begin{array}{c}\text { Semester } \\
\text { VII }\end{array}$ \\
\hline $\begin{array}{l}\text { Bila pokok bahasan } \\
\text { kimia tersebut lebih } \\
\text { bersifat abstrak }\end{array}$ & $31 \%$ & $9 \%$ \\
\hline $\begin{array}{l}\text { Reaksi yang } \\
\text { berlangsung } \\
\text { sebahagian besar sulit } \\
\text { untuk dipahami }\end{array}$ & $47 \%$ & $18 \%$ \\
\hline $\begin{array}{l}\text { Penjelasan dosen lebih } \\
\text { sering sulit untuk } \\
\text { dipahami }\end{array}$ & $20 \%$ & $9 \%$ \\
\hline $\begin{array}{l}\text { Hitungan kimia yang } \\
\text { sulit untuk dianalisis }\end{array}$ & $47 \%$ & $13 \%$ \\
\hline $\begin{array}{l}\text { Sulit untuk memahami } \\
\text { keterkaitan masing- } \\
\text { masing topik yang } \\
\text { berhubungan }\end{array}$ & $29 \%$ & $0 \%$ \\
\hline $\begin{array}{l}\text { Memahami aplikasi } \\
\text { konsep/teori } \\
\text { keseharian }\end{array}$ & $4 \%$ & $0 \%$ \\
\hline Tidak ada & $0 \%$ & $0 \%$ \\
\hline
\end{tabular}

Penyebab kesulitan yang dominan sebagaimana dijelaskan di atas adalah diantaranya karena pada umumnya di awal mula kimia dipelajari, konsep kimia yang diperkenalkan cenderung lebih banyak merupakan konsep kimia yang bersifat abstrak seperti struktur atom, ikatan kimia, yang kemudian diikuti dengan pemahaman algoritmik (hitungan matematika) kimia seperti konsep mol, laju reaksi, derajat keasaman, termokimia dan gabungan konsep 
abstrak dengan algoritmik seperti teori mekanika kuantum dan persamaan schrodinger. Konsep ini diperkenalkan di awal karena dianggap merupakan konsep dasar yang penting dan harus dipahami untuk dapat memahami ilmu kimia lebih lanjut [10][11][12][13]. Hal ini menjadi salah satu penyebab sulitnya mahasiswa memahami hubungan antara kimia teoritis dan eksperimennya, di mana pemahaman kimia yang dimiliki mahasiswa lebih pada penguasaan terhadap simbol, hafalan, rumus, dan penyelesaian masalah secara matematis, yang kemudian tidak menjadikan mereka memahaminya secara utuh dan kontekstual.

Selain identifikasi persepsi dan kesulitan mahasiswa tentang mata kuliah dan mata praktikum tersulit berikut penyebabnya dilakukan, dalam penelitian ini diamati pula hal-hal yang menjadi pendukung kesulitan mahasiswa, seperti pola belajar mahasiswa sebelum, saat dan setelah praktikum dan pandangan mereka tentang praktikum kimia itu sendiri, guna mencari benang merah keterkaitan pandangan akan 'sulitnya praktikum kimia' bagi mereka dengan sejauhmana upaya mereka menyelesaikan kesulitannya. Hasilnya sebagaimana terlihat pada Gambar 2 sampai dengan Gambar 6.
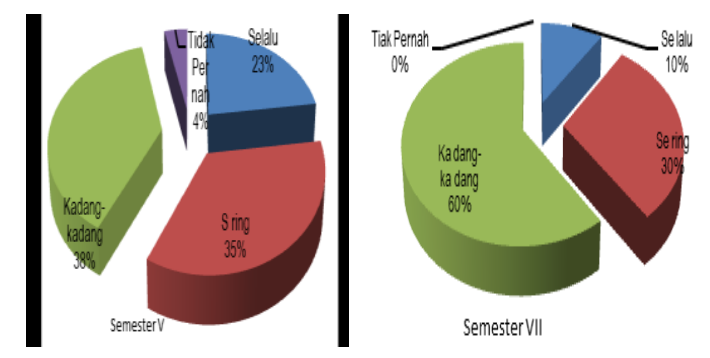

Gambar 2. Kuantitas Persiapan Mahasiswa Menghadapi Praktikum

Pada Gambar 2 terlihat bahwa baik mahasiswa semester V maupun semester VII, lebih dari 50\% dari mereka mengatakan lebih sering bahkan selalu mempersiapkan diri dan belajar hanya ketika akan ada evaluasi. Ini menunjukkan masih lemahnya kesadaran mereka dalam memahami pentingnya mempersiapkan praktikum dengan mempelajari konsep dan teori dibalik praktikum tersebut. diantaranya adalah rendahnya tingkat pengetahuan mahasiswa dalam memahami hampir setiap percobaan yang akan mereka hadapi, yang ditandai dengan rendahnya sebahagian nilai pre-test mereka. Setelah selesai praktikum, identifikasi terhadap hasil post-test mereka yang baik juga hanya terbatas pada pengetahuan yang terkait dengan objek praktikum. Pemahaman mereka terhadap pelaksanaan praktikum dan pengembangannya, pengetahuan akan implementasi dalam keseharian, interpretasi data hasil dan kaitannya dengan 'prior knowledge' mereka juga masih rendah. Untuk itu diperlukan penelitian lebih lanjut terkait dengan pemecahan masalah ini.

Selama kegiatan praktikum, kuantitas mahasiswa dalam bertanya juga masih rendah, sebagaimana terlihat pada Gambar 3. Gambar ini menunjukkan bahwa kuantitas mahasiswa yang bertanya dalam perkuliahan masih sangat rendah. Sejalan dengan bertambah lamanya perkuliahan ternyata tidak menjadikan mahasiswa semakin ingin bertanya secara signifikan. Hal ini terlihat dari perbedaan kecenderungan mahasiswa yang hanya sedikit lebih baik setelah bertambahnya 1 tahun perkuliahan yang mereka lalui.

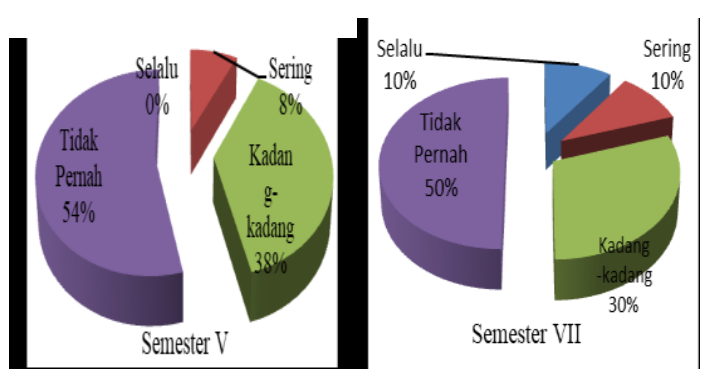

Gambar 3. Kuantitas Mahasiswa Bertanya dengan Dosen saat praktikum,

Analisis lebih lanjut menunjukkan bahwa sebahagian besar mahasiswa lebih memilih bertanya/berdiskusi dengan teman dan asisten ketimbang langsung ke dosen pembimbing. Padahal, pemahaman mereka tentang praktikum masih sangat rendah, sebagaimana terlihat pada Gambar 4. 


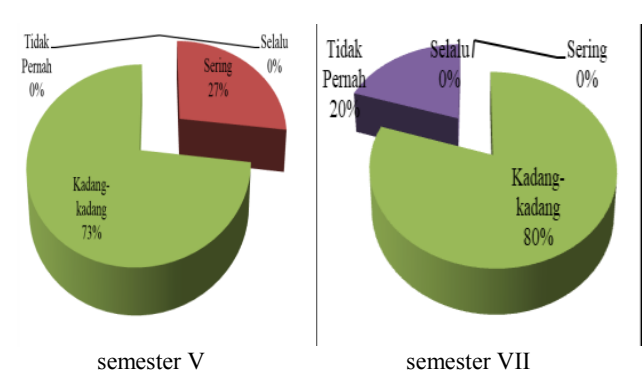

Gambar 4. Kuantitas Kepahaman Mahasiswa a manfaat setiap pokok bahasan praktikum yang telah dilaksanakan

Gambar di atas menunjukkan bahwa paa mahasiswa semester V 27\% diantara mahasiswa seringkali tidak memahami manfaat praktikum yang mereka laksanakan, dan kuantitas ini menghilang sama sekali di semester VII. Hanya sesekali mereka kurang memahami manfaat praktikum. Hal ini menunjukkan bahwa latihan eksperimen yang mereka laksanakan memberikan waktu dan kesempatan bagi mereka untuk belajar memahami hubungan eksperimen dengan pemahaman mereka.

Kondisi lainnya adalah adanya penuntun praktikum untuk panduan pelaksanaan praktikum di laboratorium. Penuntun ini diharapkan dapat memudahkan mahasiswa melaksanakan tata urut penemuan hasil praktikum. Namun penuntun ini memiliki kelemahan dalam beberapa hal, diantaranya tidak memberikan kesempatan untuk mempelajari desain percobaan, investigasi, hasil analisis kritis, dan penyebab kegagalan.

Dalam kaitannya dengan keterbatasan waktu dalam laboratorium, para mahasiswa juga sering harus berjuang keras untuk mengatasi berbagai kesulitan lain seperti pengukuran dan teknik laboratorium tidak familiar, sementara mereka diharapkan untuk dapat menginterpretasikan data yang diperoleh. Hal ini memberi beban kognitif tersendiri pada mahasiswa karena pada umumnya prosedur praktikum yang disediakan oleh dosen sering membuat mahasiswa terjebak pada kesulitan yang mengarah pada lower order cognitive skill dan mengganggu pencapaian target pembelajaran yang diharapkan kearah higher order cognitive skill.
Selain itu, meskipun percobaan praktikum tersebut terlihat sederhana, namun banyak mahasiswa yang mengalami kesulitan dalam mengabstraksikan, memvisualisasikan atau mengimajinasikan apa yang terjadi pada level molecular yang dalam kaitannya dengan kekhasan makroskopik dapat menimbulkan miskonsepsi

Ditambah lagi jika dilihat dari pola belajarnya mereka, terlihat bahwa kesungguhan mahasiswa mempersiapkan diri mengikuti praktikum juga masih kurang baik. Ini terlihat dari kurangnya upaya mereka mempersiapkan diri terhadap praktikum yang akan dilaksanakan. Hal ini mungkin terjadi karena kurang menariknya praktikum bagi mereka, atau budaya belajar yang butuh untuk ditingkatkan, juga peran dosen dalam hal ini.

Kendala minimnya sarana dan prasarana merupakan keterbatasan yang menjadi hal yang perlu diperhatikan selain dan rendahnya budaya mutu belajar aktif dan kreatif mereka. Maka upaya- upaya perlu dilakukan untuk mengatasi keterbatasan ini.

Untuk mengatasi kendala ini, diperlukan suatu rancangan program untuk membantu mahasiswa memahami konsep kimia sebelum praktikum, dan menarik minat mereka dengan desain yang dibuat sedemikian untuk menumbuhkan minat mereka, selain memfasilitasi konstruksi pengetahuan mahasiswa dalam suatu lingkungan laboratorium simulasi dengan menyediakan metode yang berbeda untuk memberi kesempatan pada mahasiswa terlibat dalam aktivitas kognitif yang sebelumnya diluar jangkauan mereka[15].

Dengan melakukan tugas yang menuntut lower level skills, SimuLab mengurangi beban kognitif mahasiswa dan membiarkan perhatian mahasiswa langsung mengarah pada proses tingkat yang lebih tinggi (higher order processes) dan menyediakan ruang lebih untuk scientific reasoning. Investigasi penelitian secara jelas mengindikasikan bahwa pembelajaran program simulasi meningkatkan kemampuan konstruksi berfkir mahasiswa, selain hemat biaya, dan dengan waktu dan tempat yang 
dapat ditentukan mahasiswa, dimana hal ini sulit untuk mereka peroleh di laboratorium riil [16].

Sesungguhnya, pembelajaran melalui eksperimen di laboratorium memiliki sangat banyak manfaat bagi mahasiswa, yang disadari atau tidak dapat mereka peroleh baik secara umum maupun spesifik. Pembelajaran melalui eksperimen di laboratorium tidak hanya sekedar bermanfaat dalam mengajarkan materi teori yang tidak bisa diajarkan di tempat lain, namun juga dapat menumbuh kembangkan kemampuan psikomotorik, membiasakan mahasiswa dengan peralatan/ instrumen dan perlengkapan praktikum, merancang dan mengkonstruksi peralatan percobaan, meningkatkan kemampuan mengamati, mengumpulkan dan interpretasi data, argumentasi yang bagus dan terarah, belajar mandiri, mendorong kemandirian berfikir, merangsang pemikiran yang mendalam mengenai interpretasi percobaan, meningkatkan keahlian mahasiswa dalam pemecahan masalah dengan variabel berjumlah besar dan banyak kemungkinan cara pemecahannya, mendorong inisiatif, semangat berusaha, dan pemberdayaan akal, meningkatkan tanggung jawab dan keandalan personal untuk melakukan percobaan, menanamkan kemampuan mengukur secara tepat dan seksama, menumbuhkembangkan kepercayaan/keyakinan pada kemampuan diri, memperkuat keyakinan akan kebenaran teori-teori, menanamkan kemampuan merancang percobaan dan menafsirkan data yang diperoleh, melatih penulisan laporan teknik, memuaskan keingintahuan peserta didik, menumbuhkembangkan sikap ilmiah dan pemahaman tentang metologi ilmiah/ rekayasa melalui penyelidikan eksperimental (Rahayuningsih \& Dwiyanto, 2005). Sangat disayangkan jika mahasiswa tidak memperoleh sedemikian banyak kemampuan yang semestinya menjadi bekal mereka sebagai calon guru kimia. Upaya dari pendidik dan institusi harus terus dilakukan guna peningkatan kualitasnya.

\section{SIMPULAN}

Hasil penelitian menunjukkan bahwa mata praktikum tersulit bagi mahasiswa semester $\mathrm{V}$ adalah praktikum Kimia Fisika dan Kimia Analitik, dan untuk praktikum kimia Instrumen yang menurut mahasiswa semester VII yang sejalan dengan pada kimia teoritis kesulitan mahasiswa lebh pada materi kimia yang bersifat abstrak dan hitungan.

Sarana dan prasarana yang belum tersedia optimal menjadi pendukung sulitnya praktikum instrumentasi bagi mahasiswa semester

Jika dilihat dari pola belajar mahasiswa, terlihat bahwa kesungguhan mereka mempersiapkan diri mengikuti praktikum juga masih kurang baik. Ini terlihat dari kurangnya upaya mereka mempersiapkan diri terhadap kegiatan perkuliahan dan praktikum yang akan dilaksanakan.

Kurang menariknya praktikum bagi mereka, atau budaya belajar yang butuh untuk ditingkatkan, juga peran dosen menjadi salah satu hal yang perlu diperhatikan.

Dibutuhkan suatu rancangan program yang didesain sedemikian untuk membantu mahasiswa memahami konsep kimia sebelum praktikum, dan menarik minat mereka dengan desain yang dibuat sedemikian untuk menumbuhkan minat mereka, juga untuk memfasilitasi konstruksi pengetahuan mahasiswa serta memberi kesempatan pada mahasiswa terlibat dalam aktivitas kognitif yang sebelumnya diluar jangkauan mereka.

\section{DAFTAR PUSTAKA}

[1]. Reid, N. \& Shah, I. "The Role of Laboratory Work in University Chemistry". Chemistry Education Research and Practice, 8(2), hlm. 17285, 2006.

[2]. Jeronen, E. \& Pikkarainen, E. "Overcoming the gap between theory and practice in subject teacher education: The role of subject didactics, general didactics and the theory of pedagogical action". TNTEE. 2(1), hlm. 237-247, 1999.

[3]. Josephsen, J \& Kristensen, A.K. "Simulation of laboratory assignments to support students' learning of 
introductory inorganic chemistry". Chemistry Education Research and Practice, 7 (4), hlm. 266-279, 2006.

[4]. Limniou, M., Papadopoulos, N., Giannakoudakis, A., Roberts, A., \& Otto, O. "The integration of a viscosity simulator in a chemistry laboratory". Chemistry Education Research and Practice. 8 (2), hlm. 220-231, 2007.

[5]. Kurniawati, Y., Permanasari, A., \& Muzakir A.'Kemampuan bereksperimen sintesis senyawa anorganik \& interelasinya dengan penguasaan konsep kimia anorganik pada mahasiswa calon guru kimia". Jurnal Pendidikan IPA Indonesia, 2(1), hlm. 57-64, 2013.

[6]. Creswell, J.W. \& Clark, V.L.P. Designing and Conducting Mixed Methods Research. London: Sage Publications, 2007.

[7]. Ercan, F \& Taşdere, A. "Identification of teacher candidates' skills in designing experiments with various assessment tools". Western Anatolia Journal of Educational Sciences, Spec. Issue, hlm 231-238, 2011.

[8]. Bradley, J.D. \& Brand, M. "Stamping out misconceptions". Journal of Chemical Education, 62(4), hlm. 318, 1985.

[9]. Treagust, D.F., Chittleborough, G., \& Mamiala, T. L. "The Role of Submicroscopic and Symbolic Representations in Chemical Explanations". International Journal of Science Education, 25, hlm.1353-1368, 2003.

[10].Nakhleh, M. "Why some students don't learn chemistry: chemical misconceptions". Journal of Chemical Education, 69(3), hlm.191-196, 1992.

[11].Ayas, A., \& Demirbaş, A. "Turkish secondary students' conception of introductory chemistry concepts". Journal of Chemical Education, 74(5), hlm. 518-521, 1997.

[12].Coll, R.K. \& Treagust, D.F. 'Learners' use of analogy and alternative conceptions for chemical bonding".
Australian Science Teachers Journal, 48(1), hlm 24-32, 2001.

[13].Nicoll, G. "A report of undergraduates' bonding alternative conceptions". International Journal of Science Education, 23(7), hlm. 707-730, 2001.

[14].Rahayuningsih, E. \& Dwiyanto, D. (2005). Pembelajaran di Laboratorium. Yogyakarta: Pusat Pengembangan Pendidikan Universitas Gadjah Mada.

[15].Supasorn, S, Jones, D., and Vibuljan, V. "Impact Of A Pre-Laboratory OrganikExtraction Simulation On Comprehension And Attitudes Of Undergraduate Chemistry Students Chemistry Education Research and Practice, 9, hlm.169-181, 2008.

[16].Josephsen, J and Kristense, A. "Simulation Of Laboratory Assignments To Support Student's Learning Introductory Inorganic Chemistry. Department of Life Sciences and Chemistry, Roskilde University, Denmark, 2006. 